\title{
RASIO PREVALENSI ANEMIA IBU BERSALIN TERHADAP KEJADIAN PERSALINAN PRETERM DI RSUD WONOSARI TAHUN 2016
}

\author{
Noviana Dewi Rengganis*, Siti Tyastuti, Anita Rahmawati \\ Jurusan Kebidanan Poltekkes Kemenkes Yogyakarta \\ *Email: novianadrengganis@gmail.com
}

\begin{abstract}
Preterm labor is a delivery that occurs in pregnancy before 37 weeks' gestation. Complications in preterm-born infants are the single largest cause of neonatal death and are currently the leading cause of death among children under 5 years. Infant Mortality Rate (IMR) in Indonesia is still very high at 34 of 1000 live births. The prevalence of preterm delivery in Gunungkidul Regency in 2013 was $16.1 \%$. Anemia is one of the causes of preterm labor. The incidence of anemia in Gunungkidul Regency has increased in the last 3 years. This study aims to determine the prevalence ratio of maternal anemia on the occurrence of preterm labor in Wonosari Hospital 2016. Type of observational analytical research with cross sectional design. The subject of this research is maternity mother in RSUD Wonosari. Data collection was taken from secondary data that is maternity register and medical record from January to December 2016. Target population in this study amounted to 953, with simple random sampling. The number of samples in this study amounted to 208 respondents. Data were analyzed using Ratio Prevalensi (RP). Preterm birth mothers with anemia of 38,5\% and preterm birth mothers who did not have anemia of $18.2 \%$ with analysis of $R P=2,115$. The result indicates that maternal mother with anemia has a chance to experience preterm labor 2.115 times bigger than mothers who are not anemia. (Cl:1,330-3,365).
\end{abstract}

Keywords : Preterm, Anemia, Maternity

\section{ABSTRAK}

Persalinan preterm adalah persalinan yang terjadi pada kehamilan sebelum usia gestasi 37 minggu. Komplikasi pada bayi yang lahir preterm merupakan penyebab tunggal terbesar kematian neonatal dan saat ini menjadi penyebab utama kematian di kalangan anak-anak di bawah 5 tahun. Angka Kematian Bayi (AKB) di Indonesia masih sangat tinggi yaitu mencapai 34 per 1000 Kelahiran Hidup $(\mathrm{KH})$. Prevalensi kejadian persalinan preterm di Kabupaten Gunungkidul pada tahun 2013 sebesar 16,1\%. Anemia merupakan salah satu peyebab persalinan preterm. Kejadian anemia di Kabupaten Gunungkidul mengalami peningkatan dalam 3 tahun terakhir. Penelitian ini bertujuan untuk mengetahui besar rasio prevalensi anemia ibu bersalin terhadap kejadian persalinan preterm di RSUD Wonosari Tahun 2016. Penelitian ini adalah analitik observasional dengan desain cross setional. Subyek penelitian ini adalah ibu bersalin di RSUD Wonosari. Pengumpulan data diambil dari data sekunder yaitu register ibu bersalin dan rekam medis dari bulan Januari-Desember 2016. Populasi target dalam penelitian ini sejumlah 953, pengambilan sampel dilakukan dengan tekhnik simple random sampling. Jumlah sampel dalam penelitian ini sejumlah 208 responden. Analisis data menggunakan Ratio Prevalence (RP). Ibu bersalin preterm yang mengalami anemia sejumlah 38,5\% dan ibu bersalin preterm yang tidak anemia sejumlah 18,2\%. Hasil analisis $\mathrm{RP}=2,115$. Penelitian ini menunjukkan bahwa ibu bersalin dengan anemia berpeluang mengalami persalinan preterm 2,115 kali lebih besar dibandingkan ibu bersalin yang tidak anemia. (Cl:1,330-3,365).

Kata Kunci : Preterm, Anemia, Ibu Bersalin

\section{PENDAHULUAN}

Persalinan preterm adalah persalinan yang terjadi pada kehamilan sebelum usia gestasi 37 minggu. Menurut World Health Organization (WHO) persalinan preterm merupakan persalinan yang terjadi antara usia kehamilan 20 minggu sampai kurang dari 37 minggu yang dihitung dari hari pertama haid terakhir. Komplikasi pada bayi yang lahir preterm merupakan penyebab tunggal terbesar kematian neonatal dan saat ini menjadi penyebab utama kematian di kalangan anak-anak di bawah 5 tahun ${ }^{1}$. Angka kejadian persalinan preterm dari seluruh kelahiran adalah 7-10\% dan bertanggung jawab terhadap $85 \%$ dari semua morbiditas dan mortalitas perinatal $^{2}$. Berdasarkan hasil Riset Kesehatan Dasar (Riskesdas) tahun 2013, Angka Kematian Bayi (AKB) di Indonesia masih sangat tinggi yaitu mencapai 34 per 1000 Kelahiran Hidup (KH). Angka Kematian Neonatal (AKN) memberi kontribusi 59\% dari kematian bayi, sehingga penting untuk melakukan usaha penurunan $\mathrm{AKN}$ di Indonesia ${ }^{3}$.

Menurut laporan WHO tahun 2012 yang berjudul Born too Soon mengatakan bahwa setiap tahun diperkirakan 15 juta bayi dilahirkan secara preterm dan angka ini dapat terus meningkat ${ }^{4}$. Masalah lain yang dapat ditimbulkan persalinan preterm adalah organ vital bayi (otak, jantung, paru, dan ginjal) belum terbentuk sempurna, sehingga mengalami kesulitan dalam adaptasi untuk tumbuh dan berkembang dengan baik ${ }^{5}$.

Angka kejadian preterm secara nasional maupun daerah di Indonesia masih belum ada, tetapi angka kejadian Bayi Berat Lahir Rendah (BBLR) dapat mencerminkan angka kejadian pretermitas secara kasar $^{6}$. Berdasarkan data profil DIY tahun 2016, menunjukkan bahwa angka prevalensi BBLR paling tinggi yaitu Kabupaten Gunungkidul sebesar 6,45\% dan diurutan kedua adalah Kabupaten Kulon Progo 
sebesar $6,05 \%^{7}$. Berdasarkan hasil penelitian yang telah dilakukan oleh Vitrianingsih, Kusharisupeni, \& Luknis (2013), prevalensi kejadian persalinan preterm di Kabupaten Gunungkidul pada tahun 2013 sebesar $16,1 \%{ }^{8}$.

Beberapa faktor yang menyebabkan persalinan preterm antara lain: sosial ekonomi rendah, gizi kurang, anemia, perokok, pekerja keras, usia ibu kurang dari 20 tahun dan lebih dari 35 tahun, serta penyulit dan penyakit kehamilan lainnya ${ }^{9}$. Data profil Kabupaten Gunungkidul tahun 2015 menunjukkan angka kejadian anemia ibu hamil mengalami peningkatan dalam tiga tahun terakhir. Kejadian anemia ibu hamil di Kabupaten Gunungkidul meningkat dari $14,97 \%$ menjadi $21,88 \%$ ditahun $2015^{10}$.

Beberapa penelitian mendukung adanya hubungan antara faktor penyebab preterm, salah satunya dalam penelitian Almabruroh, Ziyadatul C, \& Alfi A (2013), menunjukkan ada hubungan anemia terhadap persalinan preterm ${ }^{11}$. Namun penelitian lain yang dilakukan oleh Amartha, Tecky A, Indri M, \& Sigit A (2014) menunjukkan bahwa tidak ada hubungan yang bermakna secara statistik antara anemia dengan kejadian persalinan preterm ${ }^{12}$.

Penelitian ini bertujuan untuk mengetahui seberapa besar rasio prevalensi anemia ibu bersalin terhadap kejadian persalinan preterm di RSUD Wonosari tahun 2016. Ruang lingkup penelitian ini termasuk dalam analisis informasi data untuk pengambilan keputusan yang tepat dalam asuhan kebidanan.

\section{METODE}

Penelitian ini menggunakan metode analitik observasional dengan desain cross sectional. Variabel independen dalam penelitian ini adalah anemia ibu bersalin, dan variabel dependen adalah kejadian persalinan preterm. Penelitian ini dilakukan pada tanggal 2 Mei 2017 sampai dengan 16 Mei 2017, tempat di RSUD Wonosari Gunungkidul.

Populasi penelitian ini adalah ibu bersalin di RSUD Wonosari tahun 2016 sejumlah 1.866 pasien. Mengingat adanya ibu bersalin yang tidak memenuhi syarat maka peneliti menggunakan populasi target. Populasi target adalah populasi yang kemudian dikenakan kriteria inklusi dan eksklusi yaitu sejumlah 953 pasien. Besar sampel minimal yang dibutuhkan sebanyak 208 dengan teknik sampling simple random sampling.

Penelitian ini menggunakan jenis data sekunder yang diperoleh dari catatan RM ibu bersalin di RSUD Wonosari Gunungkidul dalam kurun waktu 1 Januari sampai 31 Desember tahun 2016. Peneliti ingin meneliti rasio prevalensi anemia ibu bersalin dengan kejadian persalinan preterm di RSUD Wonosari. Analisis data untuk mendapatkan besar Rasio Prevalensi (RP) menggunakan program komputer SPSS 1,6.

\section{HASIL}

Tabel Karakteristik Subjek Penelitian Dapat dilihat pada tabel 1.

Tabel 1. Distribusi Frekuensi Berdasarkan Karakteristik Subjek Terpapar dan Tidak Terpapar di RSUD Wonosari

\begin{tabular}{|c|c|c|c|c|c|}
\hline \multirow{2}{*}{ No } & \multirow{2}{*}{ Karakteristik } & \multicolumn{2}{|c|}{ Preterm } & \multicolumn{2}{|c|}{ Tidak Preterm } \\
\hline & & $f$ & $\%$ & $f$ & $\%$ \\
\hline \multirow[t]{5}{*}{1.} & Usia Ibu: & & & & \\
\hline & Usia $<20$ tahun & 10 & 4,8 & 13 & 6,3 \\
\hline & Usia $20-35$ tahun & 31 & 14,9 & 106 & 50,9 \\
\hline & Usia $>35$ tahun & 10 & 4,8 & 38 & 18,3 \\
\hline & Jumlah & 51 & 24,5 & 157 & 75,5 \\
\hline \multirow[t]{5}{*}{2.} & Paritas: & & & & \\
\hline & 1 kali & 30 & 14,5 & 75 & 36,1 \\
\hline & 2 - 3 kali & 18 & 8,6 & 75 & 36,1 \\
\hline & $>3$ kali & 3 & 1,4 & 7 & 3,3 \\
\hline & Jumlah & 51 & 24,5 & 157 & 75.5 \\
\hline \multirow[t]{5}{*}{3.} & $\begin{array}{l}\text { Jarak hamil dan } \\
\text { bersalin }\end{array}$ & & & & \\
\hline & $<2$ tahun & 33 & 15,9 & 77 & 37 \\
\hline & $2-5$ tahun & 10 & 4,8 & 32 & 15,4 \\
\hline & $>5$ tahun & 8 & 3,8 & 48 & 23,1 \\
\hline & Jumlah & 51 & 24,5 & 157 & 75,5 \\
\hline \multirow[t]{5}{*}{4.} & Pendidikan: & & & & \\
\hline & Pendidikan dasar & 31 & 14,9 & 92 & 44,2 \\
\hline & Pendidikan & 19 & 9,1 & 59 & 28,4 \\
\hline & $\begin{array}{l}\text { menengah } \\
\text { Pendidikan tinggi }\end{array}$ & 1 & 0,4 & 6 & 3 \\
\hline & Jumlah & 51 & 24,4 & 157 & 75,6 \\
\hline \multirow[t]{4}{*}{5.} & Pekerjaan: & & & & \\
\hline & Bekerja & 18 & 8,6 & 67 & 32,2 \\
\hline & Tidak bekerja & 33 & 15,9 & 90 & 43,3 \\
\hline & Jumlah & 51 & 24,5 & 157 & 75,5 \\
\hline
\end{tabular}

Sumber: Data Sekunder RSUD Wonosari 
Tabel 1 menunjukkan karakteristik subjek dari 208 responden dalam penelitian ini yaitu usia, paritas, jarak hamil dan bersalin, pendidikan, dan pekerjaan ibu. Adapun penjelasan berdasarkan masing-masing karakteristik adalah sebagai berikut:

1. Usia ibu

Proporsi kejadian persalinan di RSUD Wonosari paling banyak terdapat pada usia 20-35 tahun yaitu preterm sebanyak $31(14,9 \%)$ dan tidak preterm sebanyak 106 (50,9\%).

2. Paritas

Proporsi kejadian persalinan di RSUD Wonosari paling banyak dengan paritas 1 kali yaitu persalinan preterm 30 (14,5\%) dan tidak preterm sebanyak $75(36,1 \%)$.

3. Jarak kehamilan

Proporsi persalinan dengan jarak kehamilan pada ibu bersalin di RSUD Wonosari paling banyak terdapat pada jarak <2 tahun yaitu preterm sebanyak $33(15,9 \%)$ dan tidak preterm sebanyak $77(37 \%)$.

4. Pendidikan

Proporsi ibu bersalin di RSUD Wonosari menunjukkan tingkat pendidikan yang dimiliki ibu paling banyak pada tingkat pendidikan dasar yaitu preterm sebanyak 31 (14,9\%) dan persalinan tidak preterm sebanyak $92(44,2 \%)$.

5. Pekerjaan

Proporsi ibu bersalin yang tidak bekerja lebih besar daripada ibu bersalin yang bekerja yaitu preterm sebanyak $33(15,9 \%)$ dan persalinan tidak preterm sebanyak $90(43,3 \%)$.

Tabel 2. Distribusi Frekuensi Berdasarkan Kejadian Persalinan di RSUD Wonosari

\begin{tabular}{lcc}
\hline $\begin{array}{l}\text { Kejadian } \\
\text { persalinan }\end{array}$ & $\begin{array}{c}\text { frekuensi } \\
(\boldsymbol{f})\end{array}$ & $\begin{array}{c}\text { Persentase } \\
(\mathbf{\%})\end{array}$ \\
\hline Preterm & 51 & 24,5 \\
Tidak & 157 & 75,5 \\
Preterm & 208 & 100 \\
\hline Jumlah & 200 \\
\hline
\end{tabular}

Sumber : Data Sekunder RSUD Wonosari

Berdasarkan tabel 2 diketahui bahwa subjek penelitian yang mengalami persalinan preterm 51 (24,5\%) dan tidak preterm sebanyak 157 (75,5\%).

Tabel 3. Distribusi Frekuensi Persalinan

Berdasarkan Kejadian Anemia di RSUD Wonosari

\begin{tabular}{ccc}
\hline $\begin{array}{c}\text { Kejadian } \\
\text { anemia }\end{array}$ & $\begin{array}{c}\text { frekuensi } \\
(\boldsymbol{f})\end{array}$ & $\begin{array}{c}\text { Persentase } \\
\mathbf{( \% )}\end{array}$ \\
\hline Anemia & 65 & 31,2 \\
Tidak & 143 & 68,8 \\
anemia & 208 & 100
\end{tabular}

Sumber : Data Sekunder RSUD Wonosari

Tabel 3 menunjukkan dari 208 persalinan yang memenuhi kriteria ditemukan ibu bersalin dengan anemia sebanyak $65(31,2 \%)$, presentase ini cukup tinggi karena hampir mencapai sepertiga dari jumlah seluruh sampel ibu bersalin.

Tabel 4. Hubungan Kejadian Anemia Dengan Kejadian Persalinan Preterm di RSUD Wonosari

\begin{tabular}{|c|c|c|c|c|c|c|c|c|c|}
\hline \multirow{3}{*}{$\begin{array}{l}\text { Kejadian } \\
\text { Anemia }\end{array}$} & \multicolumn{4}{|c|}{ Kejadian Persalinan } & \multirow{2}{*}{\multicolumn{2}{|c|}{ Jumlah }} & \multirow{3}{*}{$\mathbf{R P}$} & \multirow{2}{*}{\multicolumn{2}{|c|}{$\begin{array}{c}\mathrm{Cl} \\
(95 \%)\end{array}$}} \\
\hline & \multicolumn{2}{|c|}{ Preterm } & \multicolumn{2}{|c|}{$\begin{array}{l}\text { Tidak } \\
\text { Preterm }\end{array}$} & & & & & \\
\hline & $f$ & $\%$ & $f$ & $\%$ & $f$ & $\%$ & & Lower & Upper \\
\hline $\begin{array}{l}\text { Anemia } \\
\text { Tidak } \\
\text { anemia }\end{array}$ & $\begin{array}{l}25 \\
26\end{array}$ & $\begin{array}{l}38,5 \\
18,2\end{array}$ & $\begin{array}{l}40 \\
117\end{array}$ & $\begin{array}{l}61,5 \\
81,8\end{array}$ & $\begin{array}{c}65 \\
143\end{array}$ & $\begin{array}{l}100 \\
100\end{array}$ & \multirow[t]{2}{*}{$\begin{array}{c}2,11 \\
5\end{array}$} & \multirow[t]{2}{*}{1,330} & \multirow[t]{2}{*}{3,365} \\
\hline Jumlah & 51 & 24,5 & 157 & 75,5 & 208 & 100 & & & \\
\hline
\end{tabular}

Sumber : Data Sekunder RSUD Wonosari

Tabel 4 menunjukkan bahwa dari 208 ibu bersalin di RSUD Wonosari yang memenuhi kriteria inklusi dan ekslusi terdapat 51 ibu bersalin preterm yang mengalami anemia sebesar $38,5 \%$ dan yang tidak anemia sebanyak 18,2\%. Sedangkan pada $157 \mathrm{ibu}$ bersalin tidak preterm yang mengalami anemia sebesar $61,5 \%$, dan yang tidak anemia sebesar $81,8 \%$. Berdasarkan hasil penelitian, ibu bersalin dengan anemia paling banyak terdapat pada persalinan tidak preterm. Setelah dianalisis menggunakan program komputer SPSS 1,6 didapatkan Rasio Prevalensi (RP) 2,115 dan Confident Interval (Cl) 1,330 - 3,365.

\section{PEMBAHASAN}

Persalinan preterm adalah salah satu kelainan persalinan yang ditinjau dari usia kehamilan. Berdasarkan pandangan usia kehamilan, janin bisa lahir preterm, aterm, dan postterm. Persalinan preterm yaitu persalinan yang terjadi pada kehamilan 37 minggu atau kurang. Pada penelitian ini diketahui bahwa persalinan preterm yang ada di RSUD Wonosari sebesar 24,5\%. Persalinan preterm merupakan hal yang berbahaya karena potensial meningkatkan kematian perinatal sebesar $65 \%-75 \%$ selain itu juga dapat menimbulkan dampak negatif tidak hanya kematian perinatal tetapi juga morbiditas, 
potensi generasi yang akan datang, kelainan mental dan beban ekonomi bagi keluarga dan bangsa secara keseluruhan.

Persalinan preterm sulit diduga dan sulit dicari penyebabnya, menurut Manuaba dan Krisnadi terdapat beberapa faktor yang menyebabkan persalinan preterm salah satunya adalah anemia ${ }^{6,8}$. Penelitian yang telah dilakukan oleh Dian Rahmawati juga menyatakan bahwa anemia merupakan faktor risiko terjadinya persalinan preterm ${ }^{13}$. Persalinan preterm dengan anemia yang ada di RSUD Wonosari sebesar 38,5\% dari jumlah subjek penelitian.

Berdasarkan tabel 5 diketahui bahwa besar Rasio Prevalensi (RP) anemia ibu bersalin terhadap kejadian persalinan preterm di RSUD Wonosari tahun 2016 adalah sebesar 2,115. Hal ini berarti bahwa anemia pada ibu bersalin berpeluang mengalami kejadian persalinan preterm 2,115 kali lebih besar daripada ibu bersalin tidak dengan anemia.

Anemia lebih sering dijumpai dalam kehamilan, hal ini disebabkan karena dalam kehamilan keperluan akan zat-zat makanan bertambah dan terjadi perubahan pada darah dan sum-sum tulang. Perubahan hematologi sehubungan dengan kehamilan disebabkan karena perubahan sirkulasi yang semakin meningkat terhadap plasenta dan pertumbuhan payudara ${ }^{14}$. Pada penelitian ini terdapat $31,2 \%$ ibu bersalin dengan anemia, hal ini sejalan dengan penelitian yang telah dilakukan oleh Wahyuni, Sri, \& Triana menunjukkan ada hubungan antara anemia ibu bersalin dengan kejadian persalinan preterm $^{15}$. Penelitian lain juga dilakukan oleh Almabruroh, Ziyadatul C, \& Alfi A yang menyatakan bahwa ada hubungan yang bermakna antara anemia dengan kejadian persalinan preterm ${ }^{11}$

Berdasarkan analisis distribusi frekuensi pada persalinan dalam penelitian ini terdapat $24,5 \%$ ibu bersalin preterm dan $75,5 \%$ ibu bersalin tidak preterm. Sedangkan frekuensi kejadian anemia dalam penelitian ini terdapat $31,2 \%$ ibu bersalin dengan anemia dan 68,8\% ibu bersalin tidak dengan anemia. Penelitian ini juga melihat karakteristik ibu bersalin di RSUD Wonosari yaitu usia ibu, paritas, jarak kehamilan, pendidikan, dan pekerjaan. Tabel 2 menjelaskan hasil penelitian berdasarkan karakteritik subjek penelitian, dimana usia ibu pada penelitian ini paling banyak terdapat pada rentang 20-35 tahun. Ibu dengan paritas 1 kali lebih banyak terjadi dalam dalam penelitian ini. Jarak kehamilan berisiko yaitu $<2$ tahun dalam penelitian ini merupakan jarak yang paling banyak terjadi pada subjek penelitian. Pendidikan yang dimiliki ibu paling banyak adalah pendidikan dasar dan paling banyak ibu bersalin dalam penelitian ini tidak bekerja.

Hasil analisis tabel silang yang terdapat pada tabel
5 menunjukkan bahwa 38,5\% persalinan preterm mengalami anemia dan $18,2 \%$ persalinan preterm tidak mengalami anemia. Analisis data menggunakan program komputer SPSS Versi 16 didapatkan hasil rasio prevalensi yaitu 2,115. Rasio prevalensi dalam penelitian ini merupakan prevalens efek (preterm) pada kelompok dengan risiko (anemia) dibagi prevalens efek pada kelompok tanpa risiko. Confidence Interval (Cl) merupakan suatu nilai interval kepercayaan yang dihitung dengan sampel dalam penelitian, didapatkan hasil 1,330 - 3,365. Hasil tersebut dapat diartikan bahwa batas atas interval kepercayaan adalah 3,365 dan batas bawah 1,330. Dari hasil tersebut dapat diketahui bahwa nilai RP 2,115 berada pada rentang interval kepercayaan dan nilai kepercayaan di atas 1 . Sehingga dapat diartikan perbandingan kejadian persalinan preterm antara kejadian anemia ibu bersalin dengan kejadian ibu bersalin tidak anemia sebesar 2,115, angka tersebut $>1$ sehingga perhitungaan ini menunjukkan bahwa ibu bersalin dengan anemia berpeluang mengalami persalinan preterm 2,115 kali lebih besar dibandingkan ibu bersalin yang tidak anemia.

Hasil penelitian ini sejalan dengan penelitian yang dilakukan oleh Dian Rahmawati yang menunjukkan hasil bahwa anemia ibu bersalin merupakan salah satu faktor yang mempengaruhi kejadian persalinan preterm dengan $p$-value $0,001^{13}$. Penelitian lain yang menguatkan adanya hubungan anemia ibu bersalin dengan kejadian persalinan preterm dilakukan oleh Almabruroh, Ziyadatul C, \& Alfi A dengan hasil ada hubungan yang bermakna antara anemia dengan kejadian persalinan preterm ( $p$-value 0,012$)$.

\section{KESIMPULAN}

Karakteristik ibu bersalin di RSUD Wonosari tahun 2016 antaralain: usia ibu pada penelitian ini paling banyak terdapat pada rentang 20-35 tahun, ibu dengan paritas 1 kali lebih banyak terjadi daripada paritas 2-3 atau > 3 kali, jarak kehamilan berisiko yaitu $<2$ tahun paling banyak terjadi daripada jarak kehamilan 2-5 tahun atau > 5 tahun, pendidikan yang dimiliki ibu paling banyak adalah pendidikan dasar, dan paling banyak ibu bersalin dalam penelitian ini tidak bekerja. Jumlah ibu bersalin preterm dalam penelitian ini yang mengalami anemia sejumlah $38,5 \%$ dan tidak anemia sejumlah $18,2 \%$. Jumlah ibu bersalin tidak preterm dalam penelitian ini yang mengalami anemia sejumlah $61,5 \%$ dan tidak anemia sejumlah $81,8 \%$. Rasio prevalensi ibu bersalin dengan anemia terhadap kejadian persalinan preterm di RSUD Wonosari tahun 2016 adalah 2,115. Hal ini berarti ibu bersalin dengan anemia berpeluang mengalami persalinan preterm 2,115 kali lebih besar dibandingkan dengan ibu bersalin tidak anemia. 


\section{SARAN}

Saran yang dapat dikemukakan berdasarkan kesimpulan penelitian di atas adalah sebagai berikut:

1. Bagi direktur RSUD Wonosari Gunungkidul Penelitian ini diharapkan dapat dijadikan sebagai masukan dalam upaya deteksi dini anemia ibu bersalin dengan kejadian persalinan preterm, sehingga dapat segera diambil langkah-langkah efektif untuk menekan angka kejadian persalinan preterm di RSUD Wonosari Gunungkidul.

2. Bagi bidan pelaksana

Penelitian ini diharapkan dapat sebagai bahan masukan untuk meningkatkan kewaspadaan dan deteksi dini faktor risiko persalinan preterm terutama faktor risiko anemia ibu hamil yang harus dikelola sejak awal kehamilan dengan memberikan konseling yang adekuat kepada ibu hamil tentang cara pencegahan anemia selama kehamilan. Selain itu mampu berkolaborasi secara efektif dengan tim medis untuk menyusun penatalaksanaan preventif yang adekuat.

3. Bagi peneliti selanjutnya

Peneliti selanjutnya diharapkan dapat mengembangkan penelitian ini dengan menambahkan faktor penyebab lainnya serta menggunakan metode yang lebih kuat.

\section{DAFTAR PUSTAKA}

1. World Health Organization (WHO). 2015. Highlights and Key Messages from the World Health Organization's 2015 Global Recommendations. WHO.

2. Norwitz, Errol, \& John. 2007. At a Glance Obstertri \& Gynekologi. Jakarta: Erlangga.

3. Kementrian Kesehatan. 2013. Riset Kesehatan Dasar 2013. Jakarta: Badan Penelitian Dan Pengembangan KesehatanKementerian Kesehatan RI.

4. McDougall, Lori, \&Carole Presern. 2012. Born Too Soon: The Global Action Report on Preterm Birth.
New York: PMNCH.

5. Sujiyatini, Mufdillah, \& Asri. 2009. Asuhan Patologi Kebidanan. Jakarta: Nuha Medika.

6. Krisnadi, Sofie R. 2009. Prematuritas. Bandung: PT Refika Aditama.

7. Dinas Kesehatan Daerah Istimewa Yogyakarta. 2016. Profil Kesehatan DIY 2015. Yogyakarta: Dinas Kesehatan DIY.

8. Vitrianingsih, Kusharisupeni, \& Luknis. 2012. Faktor-Faktor Yang Berhubungan Dengan Berat Lahir Bayi Di RSUD Wonosari Gunungkidul Yogyakarta Tahun 2012 (Skripsi). Tidak diterbitkan. Universitas Respati Indonesia Jakarta.

9. Manuaba, IBG, Ida Ayu, \& IBG Fajar. 2012. IImu Kebidanan Penyakit Kandungan, dan KB. Jakarta: EGC.

10.Dinas Kesehatan Gunungkidul. 2016. Profil Kesehatan Gunungkidul 2015. Yogyakarta: Dinas Kesehatan Gunungkidul.

11.Almabruroh, Ziyadatul C, \& Alfi A. 2013. Hubungan Antara Anemia pada Ibu Hamil dengan Kejadian Partus Prematur di Rsud Brebes Tahun 2013 (Skripsi). Tidak diterbitkan. AKBID YPBHK.

12.Amartha, Tecky A, Indri M, \& Sigit A. 2014. Hubungan Anemia Pada Ibu Hamil Dengan Kejadian Persalinan Prematur di RSUD Ambarawa (Jurnal). Diterbitkan di Jurnal DIV Kebidanan STIKES Ngudi Waluyo Ungaran, Februari 2014.

13.Rahmawati, Dian, \& Triana. 2013. Faktor-Faktor yang Mempengaruhi Terjadinya Persalinan Preterm di RSUD DR. Moewardi Surakarta (Skripsi). Tidak diterbitkan. Fakultas Kesehatan Universitas Surakarta.

14.Prawirohardjo, Sarwono. 2010. IImu Kebidanan, Edisi keempat (Ed, Abdul Bari Saifuddin). Jakarta: Yayasan Bina Pustaka Sarwono Prawirohardjo.

15.Wahyuni, Sri, \& Triana. 2010. Hubungan Anemia Dengan Kejadian Persalinan Prematur di RSU PKU Muhammadiyah Delanggu tahun 2009 (Jurnal, Vol 1, No. 2). 